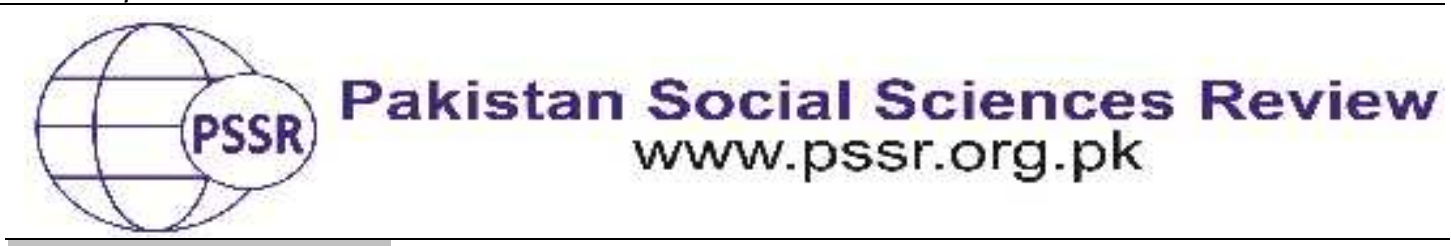

RESEARCH PAPER

\title{
Federalism and Provincial Autonomy in Pakistan: A Case of Balochistan
}

\author{
Sadia Ashraf ${ }^{1}$ Dr. Aisha Shahzad ${ }^{2}$
}

1. Lecturer, Department of Political Science, Lahore College for Women University, Lahore, Punjab, Pakistan

2. Assistant Professor, Department of Political Science, Lahore College for Women University, Lahore, Punjab, Pakistan

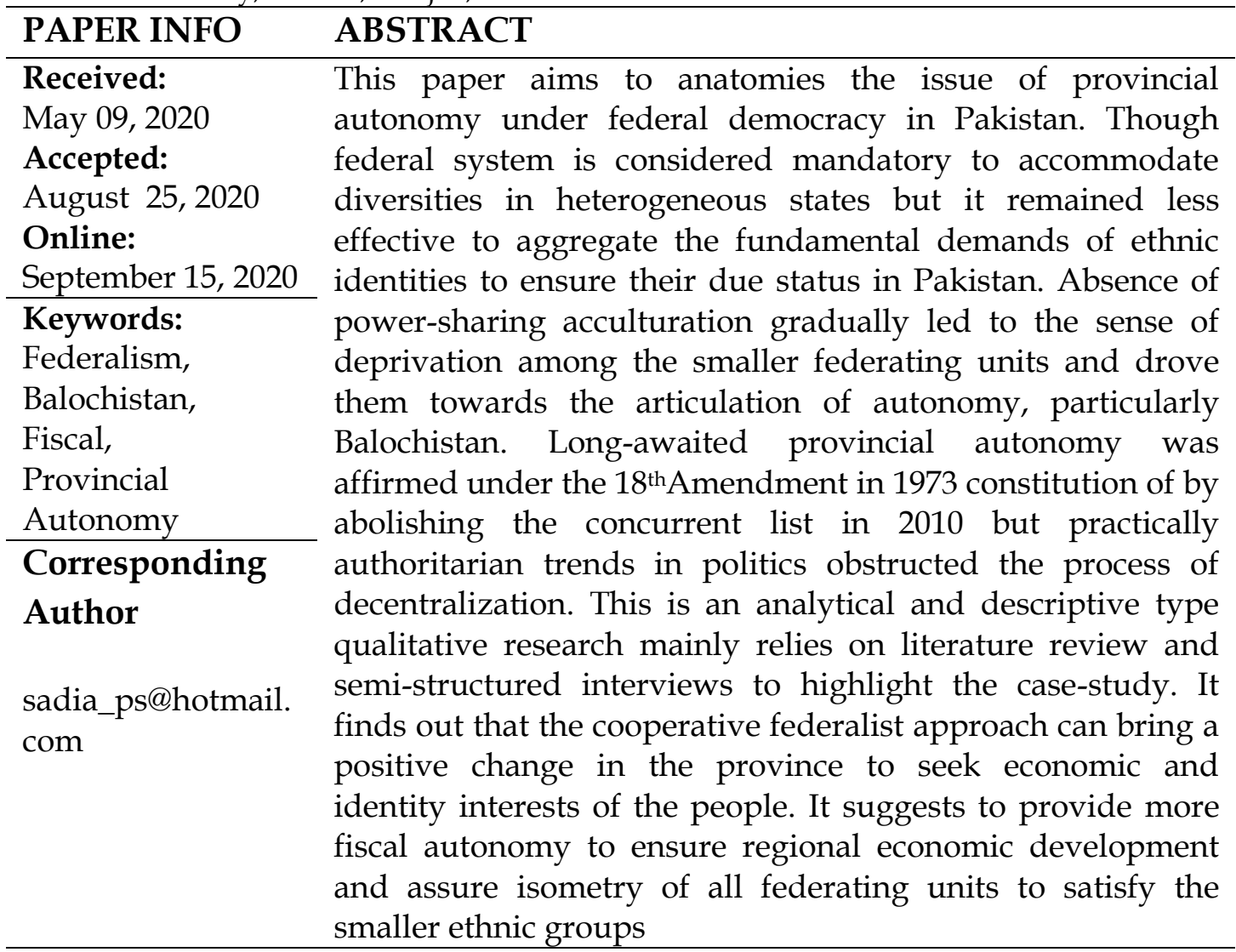

\section{Introduction}

The federal system gained popularity in multicultural societies to meet the challenges of regional diversity in terms of culture, language or economic interests. The concept of "Federalism" is based on a contract between two or more governments to develop a cooperative mechanism for smooth working. Pakistan adopted this system as a heritage of British India. However, socio-economic disparities, the concentration of power in few hands, military intervention, political 
instability, and constitutional crisis mainly led to the emergence of ethnonationalistic aspirations. The denial to acknowledge the demand for provincial autonomy by political elites caused the dismemberment of the federation and the creation of a new state-Bangladesh in 1971.

Since the very beginning, the relations between federal and provincial governments got acrimonious over several issues. Sindh, Balochistan and Khyber Pakhtunkhwa apprehended that they were being pushed back by the majority Province-Punjab. While resource-rich Balochistan always kept on demanding to get the autonomous powers that remained unaddressed. In this backdrop, several nationalist and separatist groups are presently active in the province seeking their respective agenda. Some of them claim for independence in the form of "Greater Balochistan" while others necessitate provincial autonomy.

Geographically largest and strategically significant province of Pakistan ethnically composed of native Balochs, Brahuis, Pashtuns, Hazaras, and settlers. It is producing $17 \%$ of Pakistan's total gas but consuming only two percent of it and the rest of the gas is provided to other provinces. They are receiving not more than $24 \%$ of the due royalties for supplying gas. Baloch people also express strong resentment on federal government projects like Gwadar port, CPEC and Saindak copper projects. They claim to receive only two percent out of $48 \%$ shares. Gwadar port is an extensive project but now most of the population of this area is based on settlers from Punjab and Sind, which developed a fear among local inhabitants of becoming a minority on their own land. Resultantly, there have been several insurgencies in Balochistan against the federal governments.

Moreover, Issues like target killing and missing persons became a regular feature of the province. Similarly, the Balochistan package and 7th NFC Awards show less commitment on the part of the federal government to settle their issues. Baloch nationalism and its intensive manifestation in the politics of Pakistan reflect the incompetence of the federal authorities in resolving their underlying economic and identity issues.

\section{Literature Review}

Since the evolution of the term "federalism", there has been an increasing debate over its definition. Thus, it's not quite easy to define the word federalism, considering that various scholars have different views on its meanings. According to Wheare, "the federal system is a method of dividing power so that regional governments are placed within a framework of coordination and interdependence" (Wheare, 1947). Sir Robert Garran, in his report on the royal commission on the Australian constitution, defined federalism as a form of government in which political power is divided between the central and provincial governments so that they could work independently on their sphere (Peden, 1929).

Another scholar Watts defines federalism as "a principle of organization, whereby a concurrent demand of union achieves a compromise, and for territorial 
diversity within a society, by the establishment of a single political system, within which federal and regional governments are assigned to coordinate authority in a way that neither level of government is legally or politically subordinate to the other" (Watts, 1966, p. 12).Federalism is used mainly as the unification of some states for a common purpose with an autonomous status or powers. Its history begins with the desire of the people to be a part of the community to get mutual interests, notably trade and defense (Hicks, 1978).

Voigt and Blume (2012) explicate the major features of federal system significantly residuary powers of the provincial governments. The conjecture behind is that the competence of federalism depends upon the provincial autonomy and democratization at the lower level. The evaluation of federalism and decentralization has been presented based on data from multiple states. Assessments regarding different states unveil interesting facts that some federal states like US have a tendency towards authoritarianism mainly concerning extensive presidential powers. While on the other hand, unitary states like UK tended to adopt the devolution of powers for bolstering the culture of local empowerment.

Levy (2007) corroborates that federal arrangements are more appropriate for counterbalancing multicultural communities. This disposition visibly connects with the inclusion of all ethnicities to bring the component units from desirability to feasibility. It further propounds acceptable heterogeneity and prevents suppressed homogeneity. Ethnic groups get space to celebrate their cultural customs. There is no subversion even on the part of minority groups in the society. In the case of political, cultural, or economic disagreements, the spirit of federalism provides reasonable channels of discourses for making admissible solutions like constitutional reforms and federal, provincial accords in order to preserve democratic virtues.

(BARACSKAY, 2013) elucidates the basic parameters of cooperative federalism to bring about public policy while making collaboration with different levels of government. This study develops a comparison between the health sectors of Pakistan and Venezuela, both having authoritarian trends of governance and incapable to significantly evolve the roots of collaborative norms i.e. power-sharing and sense of accommodation. They have been facing tremendous challenges of fatal diseases like polio, measles, and virus infections; therefore, both the states need to promote inter-sectoral collaboration in terms of policy execution and surveillance. Pragmatic strategies for devolution of national policy programs also show positive results.

Rubinfeld, (1997) epitomizes the connection between federalism and economic development while incorporating all externalities. Quandaries arise due to the lack of consistency in the proper allocation of grants-in-aid that put federalism in the state of perplexity. Viable federal structures empower local governments to perform those activities which have wider spatial spill-over. It 
further leads the federal system to prevent potential inadequacies while retaining institutional balances. Federal democratic structures are preferably prone to an inclusive approach for providing representation to the local-tiers. However, overcentralization and parochialism obstruct the smooth working of different tiers of governments in developing economies. While encompassing the primary principles of cooperative federalism, the following literature review gives a historical overview of Balochistan.

Bansal (2010) explained the historical background of Balochistan that before colonial rule, this region was a fragmented province without any single governing authority. Various armies, including Persian, Sindhi, Sikh and Afghan attempted to conquer the region but could not reign over it permanently. It was only the $6^{\text {th }}$ Khan of Kalat, Nisar Khan, who established the Baloch army comprising 25,000 personnel. Balochs are the oldest inhabitants of the region who arrived here about 1,000 years ago. Several assumptions are presented about the origin of them in which the most acceptable is that they came from Aleppo (Syria) before the time of Christ, ethnically connected with Kurds and derived their language from Parthia civilization. Some perceive that they belong to Arabs or older races like Dravidians. Their lifestyle is rooted in tribalism, and they are devoted to their tribal leaders called Sardars.

Khan of Kalat remained sovereign since 1666 till 1839 when British occupied Kalat. In 1877, British government appointed Sir Robert Sandeman as an agent of governor-general who tactfully started to make relations with tribal chiefs of Balochistan to maintain peace in the area. He gave them the autonomy to handle their matters according to their values and culture. They signed a 'Treaty of Gandamak'1879 with Afghanistan under which they annexed certain areas of Balochistan with British Empire (Quetta, Bolan Pass, Chagai, Murri-Bugti areas. districts of Chaman, Peshin and Sibi). They wanted to secure a supply line with Afghanistan via Balochistan.

Grare (2006) focused that military intervention is perceived as one of the significant reasons behind the discriminatory approach towards the issues in Balochistan. The military rulers did not consider political solutions to these problems. Direct military intervention in Pakistan for more than two decades compromised democratic norms and ignored the regional identities. During the 1980s, Zia-ul- Haq allocated approximately 1.2million budget to establish seminaries in Balochistan under the Ministry for Religious Affairs to dismantle the nationalist feelings via religious schools. It also enabled the religious parties, particularly Jamiat-ul-Ulmaye-Islam, to come into mainstream politics.

Andley (2006) highlights prominent nationalist parties in Balochistan claiming rights for indigenous Baloch people. One of them is the Balochistan National Party strongly demands the utmost autonomy for the province. There is another nationalist force named Jamhoori Watan Party, confined only to the Bugti tribe. Then Baloch HaqTalwar, led by Khair Bakhsh Marri, has been a frontline party during 2005 insurgency. Fourth important group is National Party under Dr. 
Abdul Hayee. It condemns development projects in Gwadar for not providing benefits to the locals. Balochistan Students Organization is the representative of the middle class. Its main demand is to create job opportunities for youngsters. Then the Pashtun Khwa Milli Awami Party raises voice for the empowerment of all nationalities. Apart from it, Balochistan Liberation Army propagates for independent Balochistan. In fact, diverse nationalist groups have distinct political and ethnic dynamics (Muzaffar, et. al. 2018).

The impacts of CPEC on Federal politics of Pakistan though the projects of CPEC effecting positively on the economy of Pakistan but it is creating the disturbance in Centre-Provincial relations and domestic politics of Pakistan. Leaders of Balochistan and Khyber Pakhtunkhwa are raising question on current government of PTI after the elections of 2018 about the economic benefits of this projects. They have already argued and criticized over the investment of CPEC revenue on Punjab. This project will create more disturbances in Balochistan rather than regional prosperity. According to Boni, role of Council of Common Interest has become more significant after $18^{\text {th }}$ amendment and it should address the concerns of all provinces of Pakistan particularly regarding economic planning and coordination.

Moreover, People of Balochistan also have reservations against the establishment of garrisons in the most important areas i.e. Sui with gas assets, Gwadar a vital port and Kohlo- a capital of Marri tribe. It has created feelings of dispossession among the locals. Balochistan wants autonomy from federal government in their provincial matters.

A literature review helps to develop themes for interviews. The trend analysis consists of the following themes to empirically examine the data to get authentic and reliable results.

Table 1

Themes of Semi-Structured Interviews

\begin{tabular}{|c|c|c|}
\hline Code. No. & Themes & Sub-themes \\
\hline 1. & $\begin{array}{l}\text { Influence of other Ethnic } \\
\text { groups }\end{array}$ & $\begin{array}{l}\text { - The capacity of the federation to } \\
\text { manage ethnic and linguistic } \\
\text { diversities } \\
\text { - The dominance of majority ethnic } \\
\text { group }\end{array}$ \\
\hline 2. & Allocation of resources & $\begin{array}{l}\text { - Inequalities in financial resources } \\
\text { - Disequilibrium in political shares }\end{array}$ \\
\hline 3. & $\begin{array}{l}\text { Implications of } \\
18^{\text {th }} \text { Amendment }\end{array}$ & $\begin{array}{l}\text { - Unaddressed issues } \\
\text { - Regional disparities }\end{array}$ \\
\hline
\end{tabular}


The researcher conducted various in-depth and formal interviews where the respondents answered the themes mentioned above. Interview sample includes academia, politician and civil society, human rights activist in Balochistan.

Table 2

Demographic profile of Respondents

\begin{tabular}{|c|c|c|}
\hline $\begin{array}{l}\text { Code } \\
\text { No. }\end{array}$ & Category & Profile \\
\hline 1 & Politician & $\begin{array}{c}\text { Mir Hasil Bizenjo } \\
\text { Party: National Party of Pakistan } \\
\text { Office: Member of Senate since } 2019\end{array}$ \\
\hline 2 & Academia & $\begin{array}{c}\text { Prof. Dr. Kaleem Bareach } \\
\text { Department of History, University of Balochistan }\end{array}$ \\
\hline 3 & $\begin{array}{l}\text { Human } \\
\text { Rights } \\
\text { Activist }\end{array}$ & $\begin{array}{c}\text { Ismat Raza Shahjahan } \\
\text { Feminist, Human Right Activist } \\
\text { President of Women Democratic Front, Deputy General } \\
\text { Secretary of Awami Workers Party }\end{array}$ \\
\hline
\end{tabular}

The interviews are transcribed to make a trend analysis.

\section{Theme I: Influence of Ethnic Groups}

- R\#1.The first respondent expressed his views about the influence of ethnic groups that it is not a major issue in Balochistan. Baloch do not have hatred against Punjabi people or the Punjab province. It is all about the manipulation by certain institutions, particularly bureaucracy, which are working behind the unjust and unfair policies regarding Balochistan. Besides it, federal governments made many mistakes in the past about Baloch people. It started in 1948 when Prince Karim Khan surrendered but he was arrested and put into prison for ten years. The second incident happened in 1950s when thefederal government arrested Nouroz Khan. It made him a hero of Baloch people. Third time this mistake was repeated in 1973 when the government of Zulifqar Ali Bhutto dismissed the elected government of NAP with no reason, which set a stage of long term insurgency resulted in many deaths of Baloch and Armed Forces. Fourth wrong action was the killing of Akbar Bugti who never talked about independence rather autonomy, which is still being demanded. That is why, Balochistan started to perceive it as an assault on their ethnic identity. Parallel forces and military presence, missing persons issue and forced disappearances in Balochistan is also another factor contributing to pushing them towards hatred against Punjabi dominated military. However, after the demise of Bugti, Baloch nationalists killed many Punjabi settlers to vent their anger which was an undesirable act on their part.

- $\mathbf{R} \# 2$ said regarding language issue that it has been inherent in the history of the federation of Pakistan. Language is the most considerable cultural marker representing any nation; therefore, it was the basic necessity of the system to 
acknowledge regional cultures and languages to accommodate all linguistic identities for inter-ethnic harmony. However, it was entirely ignored by the federal governments in the past. The political elite in West Pakistan did not give due privilege to Bengali language. They continued the policy to assimilate all nationalities while imposing one national language. Then One-Unit system1955 lasted for almost 15 years despite the condemnation by all ethnic identities, which had long-lasting impact on the inter-provincial relations.

- R\#3 explained that Two-Nations Theory needed modification to make it more viable after the establishment of Pakistan as it is a multi-national state. Despite acknowledging the reality, Centre has imposed the Urdu language. Other languages must be given the status of national languages and should not be called regional or ethnic. This issue became major reason for ethnic movements in Balochistan as well as in Khyber Pakhtunkhwa.

\section{Theme II: Unjust and unfair allocation of resources}

- R\#1 shared that since 1947, Balochistan area remained the most neglected and deprived province of Pakistan. There is a lack of necessary facilities like health, education, water, and sanitation despite having enormous natural resources. In addition to it, the share of Balochistan under fiscal awards was not satisfied before 2009 because the sole criterion for the distribution of resources was population. However, seventh NFC Award is admitted as a considerable arrangement in favor of Balochistan first time in the history of Pakistan.

- $\quad \mathbf{R} \# 2$ talked about the seventh NFC Award that it was a positive step to handle the economic issues and provincial government of Nawab Aslam Raisani got a vast amount of money for the development of Balochistan Province. Approximately 12 million rupees were given to him in the name of Gas Royalty. Five thousand Jobs were also introduced under Aghaz-e-Haqooqe Balochistan and many Pashtun and Baloch students got employment in several departments under this package. It must be continued to prevent the young generation from becoming a puppet in the hands of anti-state actors.

- $\mathbf{R} \# 3$ explicated that praetorian interference has been a common feature in the decision-making process of Pakistan. Military got a predominant position more evidently in resource mobilization and land allocation. Furthermore, gold reservoirs of the province are in the possession of federal government. This is an alarming situation for the natives who commit to boosting up the economic conditions of their region. Suppose powers are not delegated at the local level than how can the people of Balochistan ameliorate their conditions. More autonomy means more opportunities for economic prosperity. 


\section{Theme III: Effectiveness of $18^{\text {th }}$ Amendment}

- R\#1 explained that eighteenth Amendment was welcomed and appreciated by the Baloch leadership. However, it was promised by central leadership at the time of partition that only three departments' defense, currency and foreign affairs would be given to the Centre and rest of the powers would remain under provincial jurisdiction. After the death of Muhammad Ali Jinnah, all promises with federating units were not fulfilled. One-Unit system was the first step to crush the rights of regional identities. Therefore, if all the provisions of $18^{\text {th }}$ Amendment were implemented in real letter and spirit, then trust between Centre and the province would be restored.

- $\quad$ R\#2 shared that federal system was not established on solid grounds. At the time of independence, the fundamental demand of all units was provincial autonomy. The leading political party in Bengal (Awami League) also raised voice for decentralization in the power structure. Previous constitutional structures distressed the smaller provinces. Nevertheless, 18thAmendment is an important contribution in the constitutional history of Pakistan, but still, many issues are unaddressed like Provincial Higher Education Commission practically does not have any power regarding independent policymaking.

- $\mathbf{R \# 3 ~ d i s c u s s e d ~} 18^{\text {th }}$ Amendment isa promising step, but a lot more is needed to do by the Centre for the satisfaction of the provinces. Factual matters have been left unresolved in it. There must be a political solution to all the problems. The locals should be incorporated in all provincial affairs like Saindak Project, Gwadar Port, Gas, Taxation, Shipping etc. Balochistan has been in favor of confederal arrangements in order to secure their regional interest. It depends upon the centre that how far generously they respond to the demands of provincial political entities.

\section{Discussion}

Since inception in 1947, the Central Government of Pakistan and provincial units had controversies over several national issues, including distribution of power, provincial autonomy, quota in services, sharing of water, royalties of natural resources, and recognition of regional cultures. Initially, the mistrust developed between Bengal and the centre regarding the status of Bengali as a national language. The situation further aggravated due to the lack of coherence between East and West Pakistan over constitutional and ethnic issues, which led to the dismemberment of East Pakistan in 1971. Federation could not embed an accommodative structure to incorporate all diversities.

No sincere effort was made to inculcate the spirit of cooperative federalism for the peaceful resolution of conflicts. In this backdrop, the structural arrangements like One-Unit 1955 to amalgamate all provinces in the western part to contain the numerical strength of the eastern wing proved an unreasonable approach on the part of the federation. Smaller provinces perceived that the larger province-Punjab 
was marginalizing them. Similarly, the relations of Balochistan as a federating unit always remained strained with the federation (Jetly, 2009).

With the dissolution of One-Unit in 1971, a new phase of federalism was started under 1973 constitution by Zulifqar Ali Bhutto. Despite having parliamentary democracy, the people of Balochistan could not be satisfied because there was no separate provincial list to empower deprived provinces. Even the concurrent list showed the supremacy of the federal government in case of any conflict. Nationalist movement, which had been seen in the province since 1947 became more violent under Bhutto regime due to discriminatory policies. According to a Baloch leader, Ataullah Mengal, Balochs are always discriminated by Punjab dominated state structure. According to him, the only difference is that military uses iron-heels, whereas civilians use sugar-coated words.

Balochistan kept on articulating the demand for autonomy since the establishment of Pakistan. In this perspective, the recent effort is $18^{\text {th }}$ Amendment in which the concurrent list was abolished and 40 subjects out of 47 were transferred to federating units. Previously, Prime Minister Zulfiqar Ali Bhutto decided to abolish the concurrent list but nothing could be done. Another major breakthrough is the increase in the share of provinces under 7th NFC award from $47 \%$ to $50 \%$ of the divisible pool for $2010-2011$ and $57.5 \%$ for the following four years. Progressive criteria for the award benefited the provinces immensely. Factors such as poverty, revenue generation and inverse population density, in addition to population, were recognized for the determination of award. The award also changed the ratio of the provincial share, Punjab - 51.74\%, Sindh - 24.55\%, NWFP - $14.62 \%$ and Baluchistan $9.09 \%$.The following figures show the greater share for Balochistan (Yang, 2010).

Figure 1: Revenue Sharing formula of Seven NFC Award

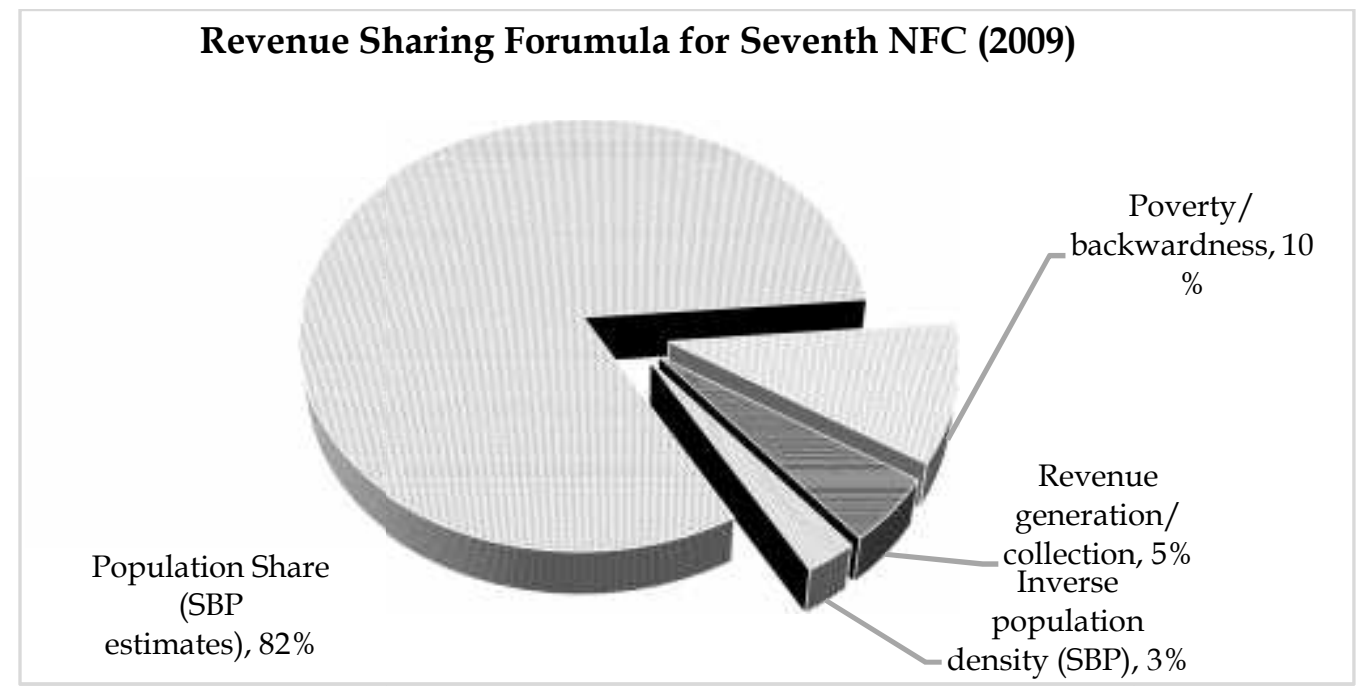

Source: Statistical Bureau of Pakistan - A Quarterly Report 2010 
Figure 2: Province-wise Revenue share under Seventh NFC Award

\section{Province wise revenue share under Seventh NFC Award}

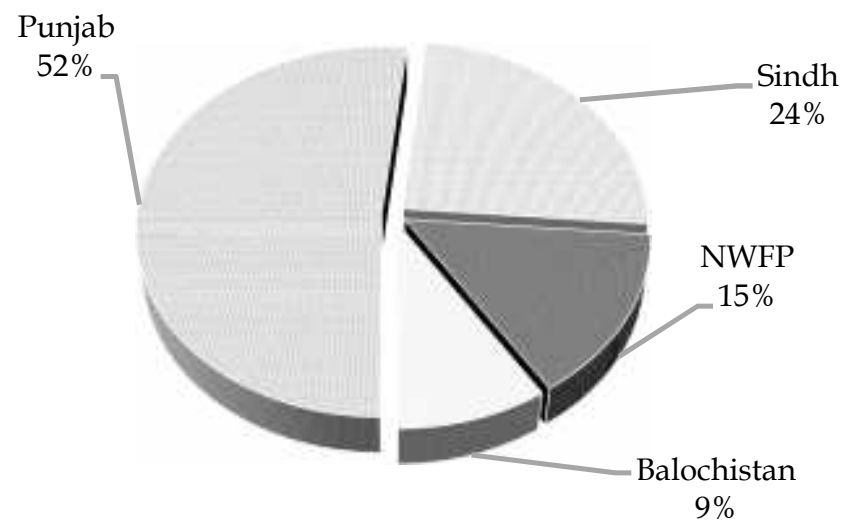

Source: State Bank of Pakistan - First Quarterly Report 2010

Amendment has made it obligatory that the share of a province in the new award would never be less than received earlier. There is also a provision for the annual monitoring of the implementation of the award. The Monitoring Report has to be presented to National and Provincial assemblies. As far as resources are concerned, equal ownership is provided on the mineral assets discovered in provinces. However, taxation is not entirely transferred to the provinces (Rashid, 2010). The federal government is still having full control over recruitments of bureaucracy, appointments of governors, and the judges of the high courts. Federal government established Council of Common Interest (CCI) as an advisory body to communicate with all federating units as well as to settle down the intergovernmental disputes, but its role is also ineffective. There are few meetings called by it with a considerable gap. It raised a question of provincial autonomy again with an objection of involvement of establishment in all matters.

Along with other provinces, Balochistan pointed out the unfavorable conditions for provinces even after enhancing autonomy. Balochistan is still deprived of the right to utilize its own resources of oil and gas. Over a period, the provincial authorities have been claiming their right to attain more powers in regional matters. The respondents also endorsed that the Baloch were kept far behind than other federating entities creating sense of marginalization among them. Cooperative federalism necessitates the proper allocation of resources along with due responsibilities in order to ensure productive collaboration between the central government and all the federating units. It is significant for reinforcing democratic norms primarily in multi-ethnic states. While emphasizing the accountability of the elected representatives, it fosters participatory political culture. However, it is closely related to neo-liberalism promoting unity within diversity, more precisely national cohesion in multiculturalism. 
Sound and sustainable fiscal policies, along with the maximum prospects for employment, become mandatory for the inner stability of federation. These are the indicators to evaluate the performance of the government about the fair distribution of resources. Moreover, public policies based on equity set the normative standard for anatomizing different organs of government. Provincial authorities diversify their fiscal programs to generate more money instead of encumbering the masses with unfair taxation. In this regard, the role of regulatory agencies appears more pronounced for public good. The cooperative federal approach is more feasible to sustain trust and coherence between Centre and the province of Balochistan. It further needs a passable mechanism based on political reconciliation to avoid detrimental inter-provincial or intra-provincial conflicts.

Disagreements between central and lower tiers of governments are better resolved by political cooperation through institutions rather than adjudication. Well-grounded strategies, along with regular national and local body elections, are essential for the solidarity of the federation. These arrangements assuage competition among divergent ethnic groups. Similarly, free riders are also appropriately appeased. Federal system is founded on bargains with confidencebuilding measures. Negotiations and reconciliations are inherent to evolve normative conditions for federalism; for that reason central government and Balochistan can better derive the areas of mutual cooperation.

Confrontations between central and provincial governments are intrinsic in multi-ethnic states, but federal structures are responsible for transforming conflicts for a peaceful resolution. The people of Balochistan perceived that the federal structure did not enhance its capability for providing autonomy to facilitate them. The identity politics escalated tensions, paving the way for the centrifugal forces in the region. It made the Balochs to pursue their group interests specifically to put pressure on state authorities to retain a proportionate share in leading institutions. The nationalist elements maintained their tactic of identity-building, simultaneously generating resentment against others. They mobilized their community for their equal status in the federation to counter unjust treatment by the government. They reiterated to empower their people.

Arguably, they had been demanding for power-sharing and representative political system but the lack of futuristic policies by the previous governments made this task formidable due to its unwise policy framework. A mere amalgamation of different ethnic groups either in the name of religion or national integration did not prove viable. Leading institutions of the state i.e. army and bureaucracy consumed resources to equip themselves instead of empowering the deprived Balochistan people. Then the Sardari system and the dynamics of tribalism were not incorporated by the centre for co-existence.

The civilian governments needed to lay a strong foundation for a federal parliamentary democracy while fulfilling its rudiments like the culture of political negotiations with patience and acceptability for the opponents. Correspondingly 
the indigenous leadership in Balochistan did not develop a mechanism to gradually update their systems and institutions to meet the challenges of modern time. On the other hand, the central governments since 2010 did not endeavor to increase the capacity of the provincial institutional set-up in Balochistan to avail new opportunities under the $18^{\text {th }}$ Amendment.

\section{Conclusion and Recommendations}

This research concludes that local leaders should be engaged through the parliamentary committee on Balochistan with the spirit of implementation to create trust and confidence. There is a need to stop building more military garrisons and to promote provincial security forces. It is agreed that military solutions to these problems led local people towards insurgency. Baloch leaders emphasized the policies of equalization to promote peace in the region. It could generate a sense of ownership among people necessary to contribute to national prosperity. However, over-centralization created a sense of alienation and deteriorated Centre-Province relations. In addition to it, the incompetent political parties caused the preeminence of bureaucracy in the administrative structure of Pakistan. The rivalry between politicians and civil servants affected the political process. The policymaking remained under the ascendancy of bureaucracy.

The federal democratic system is fortified with the dispersal of powers more profoundly to incorporate the smaller ethnic groups. It reduces the chances of identity issues. This study suggests, more fiscal autonomy ensures regional economic development. People become empowered when they get what they deserve. That appears to have an opportunity to retain their status in the mainstream policy framework. It is the dilemma of the political system of Pakistan that extensive local body system has not been established even after seventy years. Indeed, devolution of powers at the grassroots is equally important to strengthen the foundation of the federation. It also recommends to shift CPEC/Gwadar offices to Balochistan and to indulge Local people in economic and administrative dealings and activities. For that purpose, both Central and Provincial Governments with collaboration can start Technical Training Centers for local people. Furthermore, Federation should recognize the mother Languages of all ethnic identities in Pakistan leastwise at provincial level if it is not possible at national level. 


\section{References}

Andlley, P. (October 2006). Balochistan: A Backgrounder, New Dehli: Institute of Peace and Conflict Studies (IPCS Report).

Bansal, A. (2010). Balochistan In Turmoil. New Dehli: Manas Publications.

Baracskay, D. (Fall 2013). Comparative Federal Health Care Policy: Evidence of Collaborative Federalism in Pakistan and Venezuela. Journal of Health and Human Services Administration, 36 (2), pp 124-163.

Grare, F. (January 2006). Pakistan: Resurgence of Baluch Nationalism (Number.65). Washington DC: Carnegie Papers.

Hicks, U.K. (1978). Federalism, Failure and Success : A Comparative Study. London: Hicks, Ursula Kathleen.

Jetly, R. (2009). 'Resurgence of the Baloch Movement in Pakistan: Emerging Perspectives And Challenges' In Jetly, R (Eds). Pakistan In Regional And Global Politics. India: Routledge.

Levy, J. T. (2007). Federalism, Liberalism, and the Separation of Loyalties. American Political Science Review, 101(3), p 461.

Muzaffar, M. Karamat, S. \& Saeed, K. (2018). Balochistan Insurgency: Causes and Prospects, Orient Research Journal of Social Sciences, Volume 3, Issue 1, 112-128.

Peden, J. B. (1929). Report of the Royal Commission on the Constitution. Canberra: Government Printer.

Rashid, A. (Winter, 2010). Fiscal decentralization: Empowering the provinces, strengthening the federation. The Pakistan Development Review, 49(4), pp. 279-282.

Rubinfeld, D.L. (October 1997). On Federalism and Economic Development. Virginia Law Review, 83 (7), pp 1581-1592.

Voigt, S. \& Blume, L. (April 2012). The Economic Effects of Federalism and Decentralization - A Cross Country Assessment. Public Choice, 151 (1/2). pp 229-254.

Watts, R. (1966). New Federations: Experiments In The Common Wealth. Oxford: Clarendon Press.

Wheare, K. (1947). Federal Government. New York, London: Oxford University Press.

Yang, C. (Summer, 2010). Ending Dictatorship: Pakistan's Eighteenth Amendment. Harvard International Review, 32(2), pp. 10-11. 